$1 \quad$ Research article

\section{2}

\title{
Microbiological quality assessment of five common foods sold at different points of sale in Burkina-Faso
}

Muller K. A COMPAORE ${ }^{1,3, *}$, Dissinviel Stéphane KPODA ${ }^{1,4}$, Bazoin S. R. BAZIE ${ }^{1,3}$, Marcelline OUEDRAOGO ${ }^{1}$, Alphonse YAKORO ${ }^{1}$, Fulbert NIKIEMA ${ }^{1}$, Asseto BELEMLOUGRI $I^{1}$, Romaric $M E D A^{1}$, Moumouni BANDE ${ }^{1}$, Nicolas BARRO ${ }^{3}$, Elie KABRE $E^{1,2}$.

${ }^{1}$ Laboratoire National de Santé Publique (LNSP), 09 BP 24 Ouagadougou 09, Burkina Faso.

${ }^{2}$ Université Joseph Ki-Zerbo, Unité de Formation et de la Recherche en Sciences de la Santé, 03 BP 7021 Ouagadougou 03, Burkina Faso.

${ }^{3}$ Laboratoire de Biologie moléculaire, d'Epidémiologie et de Surveillance des agents

Transmissibles par les Aliments (LaBESTA), Centre de Recherche en Sciences Biologiques Alimentaires et Nutritionnelles (CRSBAN), École Doctorale Sciences et Technologies, Université Joseph KI-ZERBO, 03 BP 7021 Ouagadougou 03, Burkina Faso

${ }^{4}$ Université Joseph Ki-Zerbo, Centre Universitaire de Ziniaré, 03 B.P. 7021 Ouagadougou 03, Burkina Faso

*Corresponding author: mullercompaore@yahoo.fr

\section{$\underline{\text { Abstract }}$}

The aim of the present study was to assess the microbial quality of five different types of food such as bread, pasta, rice with sauce, beans and milk sold in five localities of Burkina Faso. One hundred and one (101) samples were collected and microbial quality were assessed by evaluating the food hygiene indicators such as total aerobic mesophilic flora, total coliforms, thermotolerant coliforms, yeast and mould. Food safety indicators such as Escherichia coli, Salmonella, coagulase-positive staphylococci, Clostridium perfringens and Bacillus cereus were checked too. All samples were analyzed under ISO methods.

The results showed that $73.27 \%$ of samples were satisfactory while $14.85 \%$ were acceptable and $11.88 \%$ were not satisfactory according to international standards. Among the food safety indicators sought, Escherichia coli was detected in two samples and Bacillus cereus in four samples. Most of the analyzed food exhibited good hygiene behavior within the acceptable limits 
29 and the highest of not satisfactory rate was observed in milk powder and rice with sauce. Ouagadougou samples record the highest number of not satisfactory samples. coliforms is indicative of the poor hygiene surrounded these foods. It is therefore necessary to train and follow up the vendors in the handling of equipment, hand-washing practices and selling environment hygiene for better improvement of the quality of the street foods.

Keywords: quality, hygiene, microorganisms, street food, Burkina-Faso.

\section{Introduction}

37 Food quality is always a concern when intended to human consumption. Food-borne diseases have been increasing in recent years, with a greater impact on the health and economy of developing countries than developed countries [1]. According to World Health Organization (2020) access to sufficient amounts of safe and nutritious food is key to sustaining life and promoting good health and unsafe food containing harmful bacteria, viruses, parasites or chemical substances, causes more than 200 diseases ranging from diarrhea to cancers. An estimated 600 million (almost 1 in 10 people in the world) fall ill after eating contaminated food and 420000 die every year, including

44125000 children under the age of 5 years [2]. Common foods such as bread, beans, pasta, rice with sauce and powdered milk are common dishes suited as well as to many low-income people as to living conditions in large cities. These foods refer to street foods that play an important role

47 in developing countries such as Burkina Faso. According to the Food and Agriculture Organization, Street foods are ready-to-eat foods and beverages prepared and/or sold by vendors 49 and hawkers especially in streets and other similar public places. This definition emphasizes the retail location on the street, with foods sold from pushcarts, bicycles, baskets or balance poles, or

51 from stalls that do not have four permanent walls [3]. These street foods feed millions of people 
52 daily with a wide variety of ready-to-eat foods and beverages sold and sometimes prepared in the

53 street or public places, relatively cheap and easily accessible [4,5]. Although in developing

54 countries the informal food vending sector has in recent years grown into a lucrative trade that

55 competes with the formal sector, ignorance in regard to and inadequate knowledge of food

56 handling practices, together with a lack of formal education, have prevailed among the majority of

57 informal food handlers [6,7]. Food can serve as ideal culture medium for the growth of

58 microorganisms which can cause decomposition, spoilage and also serve as a vehicle for

59 transmission of food borne illness [8]. The food production sites are generally located either in

60 living spaces or near workplaces or on sale sites. The majority of these vending sites lacks basic

61 infrastructure and services such as potable running water and waste disposal facilities, hand and

62 dishwashing water is usually insufficient and often reused, sometimes without soap, waste water

63 is discarded in the street and garbage often disposed of in the vicinity of the stall $[6,9]$.

64 Street food quality is a concern around the world. Studies conducted in many countries such as

65 Mozambique [10], Malaysia [7,11], Brazil [12], Bangladesh [13], Kenya [14] and so on have been

66 reported. In developing countries, street foods are drove by men and women that knowledge and

67 expertise in food handling are often limited and they often engage in street food mainly to escape

68 poverty, especially as little start-up capital is required [15]. However, it is important to consider

69 the health and safety impact of these food products, because foodborne infections are more and

70 more frequent, hence the need for control strategies to ensure food safety and consumer protection.

71 According to [8] foodborne illness is a major universal health issue in developing countries due to

72 difficulties in safe guarding food from cross-contamination.

73 Burkina Faso is a land lock country neighbored by six countries, with which it shared almost the

74 same habits of street food accessibility. Vending foods on the street is a common aspect of lifestyle 
75 in countries in which there are high unemployment, low salaries, limited work opportunities and

76 limited social programs [16,17]. Foods sanitary quality controls are often limited to large urban

77 centers to the detriment of rural populations. This study is intended to investigate and shed light

78 on the microbial safety of five commons street foods sold at different points of sale in five localities

79 of Burkina-Faso.

2. Material and methods

\subsection{Sample collection and storage}

82 One hundred and one samples divided into five groups including 15 bread samples, 12 for beans

83 samples, 12 pasta samples, 19 rice with sauce samples and 43 milk powder samples were collected

84 in five localities of Burkina Faso.

85 Table I shows the repartition of all the food samples submitted to this study.

86 Table I: Repartition of the food samples

\begin{tabular}{l|ccccccc} 
Samples & Ouagadougou & Bobo-Dioulasso & Dakola & Cinkansé & Niangoloko & Quantity & Percentage \% \\
\hline Beans & 4 & 2 & 2 & 2 & 2 & 12 & $\mathbf{1 1 . 8 8}$ \\
Milk powder & 15 & 9 & 6 & 6 & 7 & 43 & $\mathbf{4 2 , 5 7}$ \\
Bread & 4 & 3 & 2 & 3 & 3 & 15 & $\mathbf{1 4 , 8 5}$ \\
Rice with sauce & 6 & 4 & 3 & 3 & 3 & 19 & $\mathbf{1 8 , 8 1}$ \\
Pasta & 3 & 3 & 2 & 2 & 2 & 12 & $\mathbf{1 1 , 8 8}$ \\
Total & $\mathbf{3 2}$ & $\mathbf{2 1}$ & $\mathbf{1 5}$ & $\mathbf{1 6}$ & $\mathbf{1 7}$ & $\mathbf{1 0 1}$ & $\mathbf{1 0 0}$
\end{tabular}

87 Sampling sites include ordinary restaurants, local markets and shops. The concerned localities were Ouagadougou, Bobo-Dioulasso, Dakola, Cinkansé and Niangoloko. All samples were taken aseptically in sterile plastic bag, kept in an insulated cold box containing ice boxes or stored at

91 until used. Figure 1 indicated the sampling localities. 
97 Parameters applied to each group of samples are those recommended by the Codex Alimentarius. cereus were investigated in milk only.

\subsection{Evaluation of the food hygiene indicators}

-Total aerobic mesophilic flora, were counted among all the food samples onto standard plate

-Coliforms that are known to be an indicator of fecal contamination were counted onto standard violet red bile lactose (VRBL) agar (Conda Pronadisa, Spain) and incubated at $37^{\circ} \mathrm{C}$ for

11224 to 48 hours under ISO 4832:1991. Only the Petri dish containing less than 150 colonies were 113 considered. 
$116 \pm 0.5^{\circ} \mathrm{C}$ for 24 to 48 hours under NF V08-017:1980. Only the Petri dish containing less than 150

117 colonies were considered.

118 - Yeast and mould were counted onto standard yeast extract glucose chloramphenicol 119 (YGC) agar (HiMedia Laboaratories, India) and incubated at $25 \pm 1^{\circ} \mathrm{C}$ for 5 days following ISO

120 7954:1988. The growth of moulds was checked every day in order to avoid invading colonies.

121 Considered Petri dish for bacterial counting were less than 150 colonies.

\subsection{Evaluation of food safety indicators}

\section{- $\quad$ Escherichia coli}

124 E. coli were identified through the IMViC test from thermotolerant coliforms. Briefly, suspected 125 colonies from thermotolerant coliforms were selected and subcultured on Nutrient Agar at $37^{\circ} \mathrm{C}$ 126 for 24 hours. Pure cultures grown on Nutrient Agar were used for Oxidase test and determination 127 of IMViC pattern (indole, methyl red, Voges Proskauer and citrate utilization test) under the 128 Standard Procedures for food Analysis. Positives clones were transferred into Levine BBLTM 129 Eosin Methylene Blue Agar (EMB) Agar France, which was incubated at $37 \pm 1^{\circ} \mathrm{C}$ for 24 hours. Escherichia coli ATCC 8739 was uses as positive control for all analyses.

- $\quad$ Salmonella spp.

132 Salmonella species were investigated according to the standard - Horizontal method for detection 133 of Salmonella spp ISO 6579:2007. Briefly, the non-selective enrichment was done by adding 25 $134 \mathrm{~g}$ of each sesame sample into $225 \mathrm{~mL}$ buffered peptone water (Liofilchem diagnostic, Italy) and 135 homogenized in a Bag Mixer (Interscience, France). Incubation was done at $37^{\circ} \mathrm{C}$ for 18 to 20 136 hours. The selective enrichment step was performed onto both tetrathionate (Müller-Kauffman) 137 (Liofilchem diagnostic, Italy) and Rappaport Vassiliadis Soy (Difco laboratories) broths incubated 138 respectively at $37 \pm 1^{\circ} \mathrm{C}$ and $42 \pm 1^{\circ} \mathrm{C}$ for 18 to 20 hours. A brilliant green at $0.95 \%$ was added to 
the selective media Tetrathionate broth in order to inhibit the growth of Gram-positive bacteria. Selective isolations were performed onto Xylose Lysine Deoxycholate (HiMedia Laboaratories, India) and Salmonella-Shigella (HiMedia Laboaratories, India) agars. Suspected colonies were purified on nutrient agar and then submitted to API 20E (BioMérieux, France) test for biochemical confirmation. Salmonella typhimurium (ATCC 14028) and Salmonella enteritidis (ATCC 13076) was used as positive control. The Key biochemical tests including the fermentation of glucose, negative urease reaction, lysine decarboxylase, negative indole test, $\mathrm{H} 2 \mathrm{~S}$ production, and fermentation of dulcitol [18].

\section{- Coagulase-positive staphylococci}

Staphylococci were isolated under ISO 6888-1:1999. Briefly, $25 \mathrm{~g}$ of each food sample were dissolved in $225 \mathrm{ml}$ of Pepton Water (Liofilchem diagnostic, Italy). and homogenized in a Bag Mixer (Interscience, France). A loop of $0.1 \mathrm{ml}$ of each sample were then seeded onto Baird Parker Agar (BP) supplemented with egg-yolk tellurite emulsion (HIMEDIA) and incubated under aerobic conditions at $37^{\circ} \mathrm{C}$ for 24 and $48 \mathrm{~h}$. The samples producing typical colonies (grey-black, surrounded by a dull halo) were considered. Biochemical confirmation to determine whenever these colonies are Coagulase positive was performed using rabbit lyophilized plasma.

\section{- Anaerobic Sulfito Reductive (ASR) bacteria and Clostridium perfringens}

ASR were isolated under ISO 15213:2003. For this purpose, $25 \mathrm{~g}$ of each food sample were dissolved in $225 \mathrm{ml}$ of Peptone Water (Liofilchem diagnostic, Italy). and homogenized in a Bag Mixer (Interscience, France). $1 \mathrm{ml}$ from each dilution were mixed with tryptose sulfite cycloserine agar and after solidification the plates were overlayed by using the same medium. After incubations at $46^{\circ} \mathrm{C}$ for 18 to $20 \mathrm{~h}$ under anaerobic condition, characteristic colonies were isolated for biochemical confirmation of Clostridium perfringens under ISO 7935:1997. Briefly, five black 
162 colonies were picked, and each was inoculated into $10 \mathrm{ml}$ of fluid thioglycolate broth. After 18 to

$16320 \mathrm{~h}$ at $37^{\circ} \mathrm{C}$, thioglycolate tubes were used to inoculated complete lactose sulfite broth containing

164 Durham tubes and then incubated at $37^{\circ} \mathrm{C}$ for 18 to $20 \mathrm{~h}$. Tubes with black butt and gas in the

165 Durham tubes are considered as Clostridium perfringens. Clostridium perfringens ATCC 13124

166 was used as a positive control for all biochemicals tests.

\section{- Bacillus cereus}

168 Enumeration of Bacillus cereus was performed by surface plating techniques of $100 \mu 1$ on

169 mannitol-egg yolk-polymyxin under ISO 7932:1993. This media use polymyxin B as the selective

170 agent and permit presumptive identification by the lecithinase reaction on the egg yolk and the

171 inability of Bacillus cereus to catabolize mannitol. The media were incubated at $35{ }^{\circ} \mathrm{C}$ for $24 \mathrm{~h}$.

172 The number of Bacillus cereus was determined after enumeration of the colonies having its

173 characteristic appearance and submitted to biochemical characterization. Bacillus cereus ATCC

17411778 was used as a positive control.

175 The appreciation criteria of microbiological quality of all food samples are enumerated in table II

176 Table II: Appreciation criteria of ready to eat meals (A) and conditioned milk powder (B);

177 Source:[19]

178 A

\begin{tabular}{llcc}
\hline & Parameters & Criteria m UFC/g & M (3m) UFC/g \\
\cline { 2 - 3 } & Salmonella & Absence $/ 25 \mathrm{~g}$ & ---- \\
& Staphylococci & $10^{2} / \mathrm{g}$ & $3 \times 10^{2} / \mathrm{g}$ \\
\multirow{2}{*}{ Ready meals } & Total aerobic mesophilic flora & $3 \times 10^{3} / \mathrm{g}$ & $9 \times 10^{3} / \mathrm{g}$ \\
& Coliforms & $10^{3} / \mathrm{g}$ & $3 \times 10^{3} / \mathrm{g}$ \\
& Thermotolerants Coliforms & $10 / \mathrm{g}$ & $3 \times 10 / \mathrm{g}$ \\
& E. coli & $10 / \mathrm{g}$ & $3 \times 10 / \mathrm{g}$ \\
& Yeast and Mould & $104 / \mathrm{g}$ & $3 \times 104 / \mathrm{g}$ \\
\hline
\end{tabular}




\begin{tabular}{|c|c|c|c|}
\hline \multirow{11}{*}{$\begin{array}{c}\text { Conditioned milk } \\
\text { powder }\end{array}$} & Parameters & Criteria m UFC/g & M (3m) UFC/g \\
\hline & Salmonella & Absence $/ 25 \mathrm{~g}$ & ---- \\
\hline & Staphylococcus aureus & $10 / g$ & $30 / g$ \\
\hline & Total aerobic mesophilic flora & $5 \times 10^{4} / \mathrm{g}$ & $1.5 \times 10^{5} / \mathrm{g}$ \\
\hline & Coliforms & $1 / g$ & $3 / g$ \\
\hline & Thermotolerants Coliforms & Absence & ---- \\
\hline & E. coli & Absence & ---- \\
\hline & Yeast and Mould & Absence & ---- \\
\hline & ASR & $10 / g$ & $30 / g$ \\
\hline & Clostridium perfringens & $1 / g$ & $3 / g$ \\
\hline & Bacillus cereus & Absence & ---- \\
\hline
\end{tabular}

182 Statistical analysis was done using IBM SPSS Statistics Version 20.0.0. and graphs were built under Microsoft Excel 2016. The mean value and standard deviation were calculated from the were significant differences $(P \leq 0,05)$ within these types of food samples.

\section{Results}

187 The results showed that out of 101 samples submitted to this study, $73.27 \%$ were satisfactory 188 according to the criteria used, while $14.85 \%$ were acceptable and $11.88 \%$ were not satisfactory 189 (Figure 2). Table III summarizes the raw results of the evaluation of the bacterial load and the 190 presence of pathogens in all the samples submitted to this study. Only $6.93 \%$ (7 samples over 101) 191 of the analyzed samples did not show any microorganism. The highest number of coliforms, total 192 aerobic mesophilic flora, thermotolerant coliforms and yeast and mould were recorded in the same 193 sample of rice with sauce in Ouagadougou and values are respectively $2 \times 10^{4}, 2.4 \times 10^{5}, 1.7 \times 10^{4}$ and 
$1941.6 \times 10^{4}$. The pathogens E. coli were found in two (02) samples of Ouagadougou namely bean and

195 pasta. On the other hand, Bacillus cereus was found in four (04) samples of milk namely two in

196 Ouagadougou and two in Cinkansé. Neither Salmonella nor Clostridium perfringens were found

197 in any samples.

198

199 Figure 2: the overall appreciation of samples quality.

200

201 Table III: Microbiological analyses

\begin{tabular}{|c|c|c|c|c|c|c|c|c|c|c|c|}
\hline $\begin{array}{l}\text { Localit } \\
\mathbf{y}\end{array}$ & Food type & $\begin{array}{c}\text { Total } \\
\text { Coliforms }\end{array}$ & $\begin{array}{c}\text { Total } \\
\text { aerobic } \\
\text { mesophili } \\
\text { c flora }\end{array}$ & $\begin{array}{l}\text { Thermoto } \\
\text { lerants } \\
\text { Coliforms }\end{array}$ & E. Coli & $\begin{array}{l}\text { Coagulase- } \\
\text { positive } \\
\text { staphyloco } \\
\text { cci }\end{array}$ & $\begin{array}{c}\text { Salmo } \\
\text { nella }\end{array}$ & $\begin{array}{l}\text { yeast } \\
\text { and } \\
\text { mould }\end{array}$ & $\begin{array}{l}\text { Anaerobic } \\
\text { Sulfito } \\
\text { Reductive } \\
\text { (ASR) }\end{array}$ & $\begin{array}{c}\text { Clostridiu } \\
m \\
\text { perfringens }\end{array}$ & $\begin{array}{c}\text { Bacillus } \\
\text { cereus }\end{array}$ \\
\hline CIN & Beans & $<1.0$ & $7.0 \mathrm{E}+01$ & $<1.0$ & $<1.0$ & $<1.0$ & Absent & $<1.0$ & - & - & - \\
\hline CIN & Beans & $<1.0$ & $3.0 \mathrm{E}+01$ & $<1.0$ & $<1.0$ & $<1.0$ & Absent & $<1.0$ & - & - & - \\
\hline NIA & Beans & $<1.0$ & $1.3 \mathrm{E}+03$ & $<1.0$ & $<1.0$ & $<1.0$ & Absent & $<1.0$ & - & - & - \\
\hline NIA & Beans & $<1.0$ & $<1.0$ & $<1.0$ & $<1.0$ & $<1.0$ & Absent & $<1.0$ & - & - & - \\
\hline DAK & Beans & $<1.0$ & $<1.0$ & $<1.0$ & $<1.0$ & $<1.0$ & Absent & $<1.0$ & - & - & - \\
\hline DAK & Beans & $<1.0$ & $7.8 \mathrm{E}+03$ & $<1.0$ & $<1.0$ & $<1.0$ & Absent & $<1.0$ & - & - & - \\
\hline ВОВ & Beans & $<1.0$ & $5.0 \mathrm{E}+01$ & $<1.0$ & $<1.0$ & $<1.0$ & Absent & $<1.0$ & - & - & - \\
\hline ВОВ & Beans & $<1.0$ & $5.0 \mathrm{E}+01$ & $<1.0$ & $<1.0$ & $<1.0$ & Absent & $<1.0$ & - & - & - \\
\hline OUA & Beans & $<1.0$ & $9.0 \mathrm{E}+01$ & $<1.0$ & $<1.0$ & $<1.0$ & Absent & $<1.0$ & - & - & - \\
\hline OUA & Beans & $1.0 \mathrm{E}+02$ & $1.2 \mathrm{E}+04$ & $4.0 \mathrm{E}+01$ & $2.0 \mathrm{E}+01$ & $<1.0$ & Absent & $<1.0$ & - & - & - \\
\hline OUA & Beans & $<1.0$ & $5.6 \mathrm{E}+03$ & $<1.0$ & $<1.0$ & $<1.0$ & Absent & $<1.0$ & - & - & - \\
\hline OUA & Beans & $<1.0$ & $1.5 \mathrm{E}+04$ & $<1.0$ & $<1.0$ & $2.9 \mathrm{E}+02$ & Absent & $4.0 \mathrm{E}+01$ & - & - & - \\
\hline CIN & Bread & $4.0 \mathrm{E}+01$ & $2.5 \mathrm{E}+02$ & $<1.0$ & $<1.0$ & $<1.0$ & Absent & $1.0 \mathrm{E}+01$ & - & - & - \\
\hline CIN & Bread & $<1.0$ & $<1.0$ & $<1.0$ & $<1.0$ & $<1.0$ & Absent & $<1.0$ & - & - & - \\
\hline CIN & Bread & $<1.0$ & $1.0 \mathrm{E}+03$ & $<1.0$ & $<1.0$ & $<1.0$ & Absent & $2.0 \mathrm{E}+01$ & - & - & - \\
\hline NIA & Bread & $<1.0$ & $2.7 \mathrm{E}+02$ & $<1.0$ & $<1.0$ & $<1.0$ & Absent & $3.0 \mathrm{E}+01$ & - & - & - \\
\hline NIA & Bread & $<1.0$ & $6.5 \mathrm{E}+03$ & $<1.0$ & $<1.0$ & $<1.0$ & Absent & 370 & - & - & - \\
\hline NIA & Bread & $<1.0$ & $8.0 \mathrm{E}+01$ & $<1.0$ & $<1.0$ & $<1.0$ & Absent & $<1.0$ & - & - & - \\
\hline DAK & Bread & $<1.0$ & $2.0 \mathrm{E}+01$ & $<1.0$ & $<1.0$ & $<1.0$ & Absent & $<1.0$ & - & - & - \\
\hline DAK & Bread & $<1.0$ & $8.0 \mathrm{E}+01$ & $<1.0$ & $<1.0$ & $<1.0$ & Absent & $<1.0$ & - & - & - \\
\hline ВОВ & Bread & $<1.0$ & $7.0 \mathrm{E}+03$ & $<1.0$ & $<1.0$ & $<1.0$ & Absent & $5.1 \mathrm{E}+02$ & - & - & - \\
\hline ВОВ & Bread & $<1.0$ & $2.7 \mathrm{E}+02$ & $<1.0$ & $<1.0$ & $<1.0$ & Absent & $1.0 \mathrm{E}+01$ & - & - & - \\
\hline ВОВ & Bread & $<1.0$ & $7.9 \mathrm{E}+02$ & $<1.0$ & $<1.0$ & $<1.0$ & Absent & $2.0 \mathrm{E}+01$ & - & - & - \\
\hline OUA & Bread & $1.8 \mathrm{E}+02$ & $1.3 \mathrm{E}+03$ & 40 & $<1.0$ & $<1.0$ & Absent & $2.0 \mathrm{E}+02$ & - & - & - \\
\hline
\end{tabular}




\begin{tabular}{|c|c|c|c|c|c|c|c|c|c|c|c|}
\hline OUA & Bread & $<1.0$ & $6.5 \mathrm{E}+02$ & $<1.0$ & $<1.0$ & $<1.0$ & Absent & $5.3 \mathrm{E}+02$ & - & - & - \\
\hline OUA & Bread & $<1.0$ & $2.0 \mathrm{E}+01$ & $<1.0$ & $<1.0$ & $<1.0$ & Absent & $<1.0$ & - & - & - \\
\hline OUA & Bread & $<1.0$ & $3.8 \mathrm{E}+02$ & $<1.0$ & $<1.0$ & $<1.0$ & Absent & $1.0 \mathrm{E}+01$ & - & - & - \\
\hline CIN & Pasta & $<1.0$ & $8.0 \mathrm{E}+01$ & $<1.0$ & $<1.0$ & $<1.0$ & Absent & $<1.0$ & - & - & - \\
\hline NIA & Pasta & $<1.0$ & $1.1 \mathrm{E}+02$ & $<1.0$ & $<1.0$ & $<1.0$ & Absent & $<1.0$ & - & - & - \\
\hline DAK & Pasta & $4.0 \mathrm{E}+01$ & $1.4 \mathrm{E}+03$ & 10 & $<1.0$ & $<1.0$ & Absent & $4.2 \mathrm{E}+02$ & - & - & - \\
\hline DAK & Pasta & $<1.0$ & $1.3 \mathrm{E}+02$ & $<1.0$ & $<1.0$ & $<1.0$ & Absent & $<1.0$ & - & - & - \\
\hline BOB & Pasta & $<1.0$ & $1.6 \mathrm{E}+02$ & $<1.0$ & $<1.0$ & $<1.0$ & Absent & $<1.0$ & - & - & - \\
\hline ВОВ & Pasta & $<1.0$ & $<1.0$ & $<1.0$ & $<1.0$ & $<1.0$ & Absent & $<1.0$ & - & - & - \\
\hline OUA & Pasta & $5.0 \mathrm{E}+01$ & $4.9 \mathrm{E}+04$ & $3.0 \mathrm{E}+01$ & $3.0 \mathrm{E}+01$ & $<1.0$ & Absent & $<1.0$ & - & - & - \\
\hline CIN & Rice+Sauce & $<1.0$ & $6.0 \mathrm{E}+01$ & $<1.0$ & $<1.0$ & $<1.0$ & Absent & $<1.0$ & - & - & - \\
\hline CIN & Rice+Sauce & $<1.0$ & $2.9 \mathrm{E}+03$ & $<1.0$ & $<1.0$ & $<1.0$ & Absent & $<1.0$ & - & - & - \\
\hline CIN & Rice+Sauce & $<1.0$ & $5.0 \mathrm{E}+01$ & $<1.0$ & $<1.0$ & $<1.0$ & Absent & $<1.0$ & - & - & - \\
\hline NIA & Rice+Sauce & $<1.0$ & $2.7 \mathrm{E}+02$ & $<1.0$ & $<1.0$ & $<1.0$ & Absent & $<1.0$ & - & - & - \\
\hline NIA & Rice+Sauce & $1 \mathrm{E}+01$ & $2.5 \mathrm{E}+03$ & $<1.0$ & $<1.0$ & $<1.0$ & Absent & $<1.0$ & - & - & - \\
\hline NIA & Rice+Sauce & $1.1 \mathrm{E}+02$ & $2.9 \mathrm{E}+04$ & $<1.0$ & $<1.0$ & $<1.0$ & Absent & $5.1 \mathrm{E}+03$ & - & - & - \\
\hline DAK & Rice+Sauce & $<1.0$ & $2.3 \mathrm{E}+02$ & $<1.0$ & $<1.0$ & $<1.0$ & Absent & $<1.0$ & - & - & - \\
\hline OUA & Rice+Sauce & $<1.0$ & $5.8 \mathrm{E}+03$ & $<1.0$ & $<1.0$ & $<1.0$ & Absent & $<1.0$ & - & - & - \\
\hline OUA & Rice+Sauce & $<1.0$ & $5.6 \mathrm{E}+03$ & $<1.0$ & $<1.0$ & $<1.0$ & Absent & $<1.0$ & - & - & - \\
\hline OUA & Rice+Sauce & $<1.0$ & $3.0 \mathrm{E}+01$ & $<1.0$ & $<1.0$ & $<1.0$ & Absent & $<1.0$ & - & - & - \\
\hline OUA & Rice+Sauce & $2.0 \mathrm{E}+04$ & $2.4 \mathrm{E}+05$ & $1.7 \mathrm{E}+04$ & $<1.0$ & $<1.0$ & Absent & $1.6 \mathrm{E}+04$ & - & - & - \\
\hline OUA & Rice+Sauce & $7.9 \mathrm{E}+02$ & $5.5 \mathrm{E}+03$ & 150 & $<1.0$ & $<1.0$ & Absent & $1.0 \mathrm{E}+01$ & - & - & - \\
\hline OUA & Rice+Sauce & $5.0 \mathrm{E}+01$ & $2.6 \mathrm{E}+03$ & 30 & $<1.0$ & $<1.0$ & Absent & $2.1 \mathrm{E}+02$ & - & - & - \\
\hline NIA & Milk & $<1.0$ & $1.8 \mathrm{E}+02$ & $<1.0$ & $<1.0$ & $<1.0$ & Absent & $<1.0$ & $<1.0$ & Absent & Absent \\
\hline NIA & Milk & $<1.0$ & $3.2 \mathrm{E}+02$ & $<1.0$ & $<1.0$ & $<1.0$ & Absent & $<1.0$ & $<1.0$ & Absent & Absent \\
\hline CIN & Milk & $<1.0$ & $2.3 \mathrm{E}+02$ & $<1.0$ & $<1.0$ & $<1.0$ & Absent & $<1.0$ & $<1.0$ & Absent & Present \\
\hline CIN & Milk & $<1.0$ & $1.3 \mathrm{E}+02$ & $<1.0$ & $<1.0$ & $<1.0$ & Absent & $<1.0$ & $<1.0$ & Absent & Absent \\
\hline CIN & Milk & $<1.0$ & $<1.0$ & $<1.0$ & $<1.0$ & $<1.0$ & Absent & $<1.0$ & $<1.0$ & Absent & Absent \\
\hline CIN & Milk & $<1.0$ & $2.8 \mathrm{E}+02$ & $<1.0$ & $<1.0$ & $<1.0$ & Absent & $<1.0$ & $<1.0$ & Absent & Present \\
\hline CIN & Milk & $<1.0$ & $4.5 \mathrm{E}+01$ & $<1.0$ & $<1.0$ & $<1.0$ & Absent & $<1.0$ & $<1.0$ & Absent & Absent \\
\hline CIN & Milk & $<1.0$ & $2.0 \mathrm{E}+01$ & $<1.0$ & $<1.0$ & $<1.0$ & Absent & $<1.0$ & $<1.0$ & Absent & Absent \\
\hline DAK & Milk & $<1.0$ & $2.0 \mathrm{E}+01$ & $<1.0$ & $<1.0$ & $<1.0$ & Absent & $<1.0$ & $<1.0$ & Absent & Absent \\
\hline
\end{tabular}




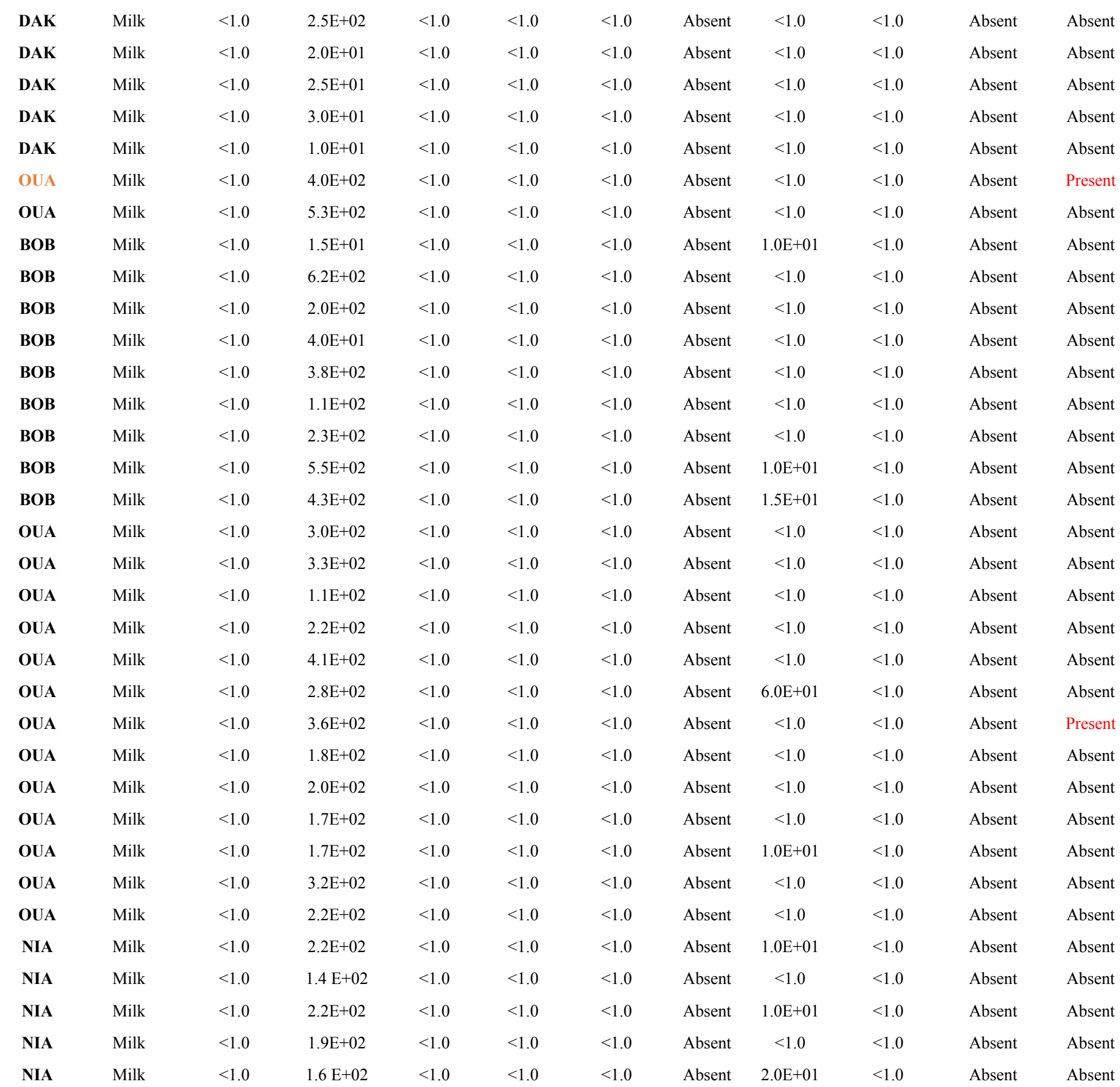

202 NIA : Niangoloko; CIN : Cinkansé ; DAK : Dakola ; BOB : Bobo and OUA : Ouagadougou.

203 Figure 3 summarizes the overall appreciation of all samples according to cities. Ouagadougou has

204 the highest number of samples and the highest number of not satisfactory (7.9\%). Off set Dakola,

205 all the other localities showed at least sample one that is not satisfactory. 
207 Figure 3: Appreciation according to cities.

209 The figure 4 gives an overview of the appreciation of the samples according to their nature. The

210 milk samples represent the highest percentage i.e., 42.57\%. All samples showed at least one case

211 that is not satisfactory. Milk powder and rice with sauce record the highest cases of not satisfactory

212 at equal value, i.e., $3.96 \%$.

$214 \quad$ Figure 4: Appreciation according to samples.

Depending on the profile of the microorganism sought, the total aerobic mesophilic flora was

217 present in $93.07 \%$ of all samples, yeast and mould in $24.75 \%$, total coliforms in $9.90 \%$,

218 thermotolerant coliforms in $6.93 \%$, E. Coli in $1.98 \%$ and coagulase-positive staphylococci in

$2190.99 \%$. Bacillus cereus was present in 9.30\% of milk sample only. Neither Salmonella and anaerobic sulfito reductive (ASR) nor Clostridium perfringens were detected in any samples.

\section{Discussion}

222 The control of foodborne pathogens is an essential measure in preventing the appearance and 223 spread of foodborne diseases in the population [20]. According to FAO (2009), unsafe food poses

224 global health threats, endangering everyone; infants, young children, pregnant women [2]. Foods

225 submitted to this study feed millions of low-income persons daily and therefore must be of very 226 good nutritional and microbiological quality.

227 Despite the relatively poor sale environment hygiene noticed on the field; these foods were in 228 general, microbiologically safe as only $11.88 \%$ were not satisfactory according to the standards 
used. Similar satisfactory results of street food were reported with breakfast and snack foods in Ghana [4], with meat and chicken stews and maizemeal porridge.in South Africa [21]. Most of the unacceptable limits derived from the total viable counts where microorganisms were present in $93,07 \%$ of samples, independently of their pathogenicity and the presence of coliforms. Total viable numbers, might come from all sources surrounding the foods, mostly from air helped by wind. The highest total viable counts recorded was $2.4 \times 10^{5}$ and was found in rice with sauce. Published papers report high total viable counts in street foods from $10^{5}$ up to $10^{9} \mathrm{UFC} / \mathrm{g}$ $[22,13,23]$. [24] report that many foods provide an environment conducive to microbial growth, and indicator counts in such foods may reflect the time and conditions of storage. Otherwise, total viable counts cannot be used as a safety indicator, as there is generally no correlation between its value and the presence of pathogens or their toxins [24]. Excepted milk samples, all foods samples submitted to our study undergo heating step that should normally reduce the microorganism population. That should be one of the reasons, we found out low total viable counts as compared to other studies. Microorganisms detected seems to have post contamination origin due to food and material handling. Street foods contamination mainly occur through hands $[5,1,11,25]$. Moreover, the presence of indicator bacteria in ready-to-eat food, although not inherently a hazard, can be indicative of poor practice that may be poor quality of raw materials or food components; undercooking; cross-contamination; poor cleaning and poor temperature and time control [26]. The presence of thermotolerants coliforms and total coliforms respectively at $6,93 \%$ and $9,90 \%$, in the study samples confirm these finding of post-processing contamination. The thermotolerant coliforms have the same properties as the total coliforms at the difference that lactose fermentation occurred at $44.5^{\circ} \mathrm{C} \pm 0.5$. However, Coliforms are known to be a possible fecal contamination indicator. That suggest the possibility of potential presence of other enteric bacteria that can be pathogens. E. coli were detected in $1.98 \%$ of study samples specifically in bean and paste samples 
253 from Ouagadougou city. Their presence in heat treated foods might therefore signifies inadequate cooking or post-processing contamination. According to [6], samples collected during the holding period after the food had already been exposed to high temperature processing, any presence of $E$.

256 coli could only be attributed to faecal contamination from the hands of food handlers and/or from 257 contaminated working surfaces and utensils. Therefore, special attention should be paid to the 258 street food chain with reference to the 5Ms (Main œuvre, Matière, Milieu, Matériels et Méthode) as decreed in the Codex Alimentarius. In addition, all food handlers must pay particular attention to their personal hygiene and hand washing after handling raw food and after using the toilet.'

261 Coagulase-positive staphylococci were detected in a bean sample of Ouagadougou at the level of $2.6 \times 10^{2}$. The main reservoir of staphylococci in humans is the nostrils, although staphylococci can also be found on hand [1]. One might think that Coagulase-positive staphylococci contamination of our bean sample comes from handling, perhaps because of more frequent hand contact during preparation and serving. Staphylococcal food poisoning is one of the most common food-borne diseases in the world following the ingestion of staphylococcal enterotoxins that are produced by 267 enterotoxigenic strains of coagulase-positive staphylococci, mainly Staphylococcus aureus [27].

268 Coagulase-positive staphylococci have been found in a large number of commercial foods by a 269 wide range of investigators $[6,27,22,23,8,14]$ but their appear to be more present with high numeration as compared to our results.

271 Yeasts and molds are commonly enumerated in foods as quality indicators and they have no 272 predictive value for the occurrence of toxigenic fungi or other pathogens[24]. They are responsible 273 of food spoilage when these foods are exposed to ambient condition without any protection. This 274 study exhibits $24.75 \%$ of yeast an molds contamination that load varying from $1.0 \times 10$ to $1.6 \times 10^{4}$ $275 \mathrm{UFC} / \mathrm{g}$. The presence of yeasts and molds in heat-treated foods might also has its roots in 
276 inadequate cooking, post-processing contamination, cross-contamination or even poor quality of

277 raw materials. [28] find out similar results on yeast load varying from 1.2 up to $5.2 \operatorname{logUFC} / \mathrm{g}$

278 while assessing the microbiological quality of ethnic street foods in the Himalayas.

279 Control parameters applied to milk samples differ from those applied to the others samples as 280 Anaerobic Sulfito-Reductive (ASR), Clostridium perfringens and Bacillus cereus were also 281 searched. Large numbers of Bacillus cereus are needed to cause illness either by releasing toxin 282 into the food prior to consumption (emetic syndrome) or by producing a different toxin or toxins 283 in the gut after eating the food (diarrheal syndrome) [26]. Bacillus cereus was isolated from only 284 four (4) milk powder samples (9,30\%). Milk powder samples submitted to this study were 285 somehow reconditioned by the vendors. The predominance of Bacillus cereus was probably due to cross contamination of bacillus spores present at the conditioning environment. Similar results 287 were obtained in South Africa where nine (9) meat/chicken samples (10.3\%) and 6 maizemeal 288 porridge samples (5.3\%) were positive for Bacillus cereus [21].

289 Dakola, Cinkansé and Niangologo localities, which are the border post cities with high traffic and 290 where food handlers lack of hygiene facilities (water supply, expertise...) like Ouagadougou and 291 Bobo, were expected to have a high contamination load. Surprisingly, Ouagadougou recorded the 292 highest rates of not satisfactory sample followed by Cinkansé. It can be hypothesized that this 293 might be due to the high number of Ouagadougou sampling (31.68\%) as compared to the other 294 samples.

295 The food safety indicators such as Salmonella, the Anaerobic Sulfito Reductive (ASR) and 296 Clostridium perfringens were not detected in any of all samples. Similar results were found in 297 South Africa while trying to determine the health risks associated with street food vending [21]. It 298 appears that important hygiene measures are practiced by almost all food handlers and this is very 
encouraging. Furthermore, the overall microbiological quality and safety of foods submitted to this research study were within the acceptable limits. One might believe that the advent of covid19 that has profoundly destabilized developing countries people and fundamentally changed their habits and behaviors might have contributed to reduce the contamination of food through handling. Indeed, the media fuss around handwashing with soap and the use of hydro-alcoholic gels have been accepted by Burkinabe around the country. One of this positive impact might be the reduction of microbial contamination through the hands.

The presence of the different type of microorganisms and the not satisfactoriness samples observed suggested a post contamination during food handling and the possible microbial attacks propagated from the surrounding environment. It is well known that infections caused by microorganisms can be reduced by maintaining correct hand hygiene. Thus, training and education can improve the knowledge of street food handlers and play an important role in risk mitigation. Specific attention should be given for storage and packing processes specific to each food is also required, and the control of water used for utensils and hands washing. That might be one of the best ways to assure constantly a good hygienic quality of street foods.

This research work highlighted that street food vendors of the study regions of Burkina Faso were able to produce relatively safe foods with low percentage of not satisfactory samples. A void that was necessary was filled, namely the quality of the meals that the average Burkinabe consumes every day, especially in border areas and urban centers. The microbial quality of these foods was acceptable in general even some fecal indicators are still presents suggesting the possibility of potential presence of other enteric bacteria that can be pathogens. As the different part of the 
322 country share the same street foods habit, one could extrapolate those similar behavioral patterns

323 may be found elsewhere within the whole country. Therefore, education and training of foods

324 handlers is crucial to control potential food borne illness. One might believe that this study is the

325 first of a series of several street foods quality control to prevent intoxication outbreak that can

326 impact negatively the economy of developing countries that is already weak.

\section{Acknowledgements}

328 This work was initiated by the PAASME-UE project ("Productions et analyses des données pour 329 améliorer la santé de la mère et de l'enfant au Burkina Faso") in collaboration with the INSP, 330 financed by the European Union. At the end of this work, it is important to thank:

331 -The National Institute of Public Health (INSP) for the scientific collaboration;

332 -The European Union (EU) for the financing of this project;

333 -The Health Research Ethics Committee for authorizing the conduct of this study;

334 -The Regional Health Directorates of the Centre, Hauts-Bassins, Cascades and Centre-East 335 regions for authorizing the conduct of this study;

336 -The populations of the Centre, Hauts-Bassins, Cascades, Centre-East and Centre-South regions 337 for their collaboration.

\section{Conflict of interests}

339 The authors have not declared any conflict of interests. 


\section{$\underline{\text { References }}$}

342 1. Soares LS, Almeida RCC, Cerqueira ES, Carvalho JS, Nunes IL. Knowledge, attitudes and practices in food safety and the presence of coagulase- positive staphylococci on hands of food handlers in the schools of Camaçari , Brazil. Food Control [Internet]. 2012;27(1):20613. Available from: http://dx.doi.org/10.1016/j.foodcont.2012.03.016

2. WHO - FAO. Food safety [Internet]. Fact Sheets. 2020 [cited 2021 Mar 23]. Available from: https://www.who.int/news-room/fact-sheets/detail/food-safety

3. FAO. Selling street and snack foods. booklet 18. Rome: Diversification; 2011. 96 p.

4. Patience M, Yeboah-manu D, Owusu-darko K, Ablordey A. Street foods in Accra, Ghana: how safe are they? 2002;80(00):546-54.

5. Barro N, Razack BA, Yollande I, Savadogo A, Tidiane OCA, Philippe NA, et al. StreetVended Foods Improvement : Contamination Mechanisms and Application of Food Safety

6. Lues JFR, Rasephei MR, Venter P, Maria M. Assessing food safety and associated food handling practices in street food vending. Int $\mathrm{J}$ Environ Health Res [Internet].

from:

7. Toh PS, Birchenough A. Food safety knowledge and attitudes : culture and environment

8. Sudeep KM, Veena K, R NE. Microbial profile of street food from different locations at hawker foodhandling practices and outbreaks of food poisoning and their prevention. 2000;11:447-52. Tumkur, India. 2017;3(2):84-9.

9. Abdussalam M, Kaferstein FK. Safety of street food. World Health Forum. 1993;14:1914.

10. Salamandane A, Silva AC, Brito L, Malfeito-ferreira M. Microbiological assessment of street foods at the point of sale in Maputo ( Mozambique ). 2021;1-9. 
11. Lian S, Abu F, Shahrim M, Karim A, Yen H. Hand hygiene knowledge, attitudes and practices among food handlers at primary schools in Hulu Langat district, Selangor. Food Control [Internet]. 2013;34(2):428-35. Available from: http://dx.doi.org/10.1016/j.foodcont.2013.04.045

12. Alves S, Cassia R De, Cardoso V, Ângelo J, Góes W, Nascimento J, et al. Street food on the coast of Salvador, Bahia , Brazil : A study from the socioeconomic and food safety perspectives. Food Control [Internet]. 2014;40:78-84. Available from: http://dx.doi.org/10.1016/j.foodcont.2013.11.022

13. Noor R. Microbiological quality of commonly consumed street foods in Bangladesh. Nutr Food Sci [Internet]. 2016;46(1):130-41. Available from: http://dx.doi.org/10.1108/NFS08-2015-0091

14. Birgen BJ, Njue LG, Kaindi DM, Ogutu FO, Owade JO. Determinants of Microbial Contamination of Street-Vended Chicken Products Sold in Nairobi County, Kenya. 2020;2020.

15. FAO. Good hygienic practices in the preparation and sale of street food in Africa Tools for training. Rome: Communication Division; 2009. 186 p.

16. Bryan F, Michanie S, Alvarez P, Paniagua A. Critical control points of street-vended foods in dominican republic. J Food Prot [Internet]. 1988;51:373-83. Available from: https://doi.org/10.4315/0362-028X-51.5.373

17. Ekanem EO. The street food trade in Africa: Safety and socio-environmental issues. Food Control. 1998;9(4):211-5.

18. Odumeru JA, León-velarde CG. Salmonella Detection Methods for Food and Food Ingredients. 2000;(Williams 1981):374-92. Available from: doi: 10.5772/29526

19. Guiraud J. Microbiologie alimentaire. 2003rd ed. Dunod, editor. France; 2003. 696 p.

20. Woh PY, Thong KL, Ai Y, Lim L, Behnke JM, Lewis JW, et al. Microorganisms as an Indicator of Hygiene Status Among Migrant Food Handlers in Peninsular. 2017;

21. Martins JH. Socio-economic and hygiene features of street food vending in Gauteng. SAJCN. 2006;19(1). 
396 22. Makelele LK, Kazadi ZA, Oleko RW, Foma R, Mpalang RK a, Ngbolua K-N, et al.

397

398

399

400

401

402

403

404

405

406

407

408

409

410

411

412

413 Microbiological quality of food sold by street vendors in Kisangani, Democratic Republic of Congo. 2015;(June).

23. Temesgen E, Eromo T, Tassew H, Daka D, Kibru G. Bacteriological Quality of Street Foods and Antimicrobial Resistance of Isolates in Hawassa, Ethiopia. Ethiop J Heal Sci. $2016 ; 26(6)$.

24. Tortorello ML. Indicator organisms for safety and quality-uses and methods for detection: Minireview. J AOAC Int. 2003;86(6):1208-17.

25. Okojie PW, Isah EC. Sanitary Conditions of Food Vending Sites and Food Handling Practices of Street Food Vendors in Benin City, Nigeria: Implication for Food Hygiene and Safety. 2014;2014.

26. Health Protection Agency. Guidelines for Assessing the Microbiological Safety of Readyto-Eat Foods. November. Health Protection Agency. London; 2009.

27. Hennekinne J, Buyser M De, Dragacci S. Staphylococcus aureus and its food poisoning toxins: characterization and outbreak investigation. 2012;36:815-36.

28. Kharel N, Palni U, Prakash J. Microbiological assessment of ethnic street foods of the Himalayas. 2016;3:235-41. 


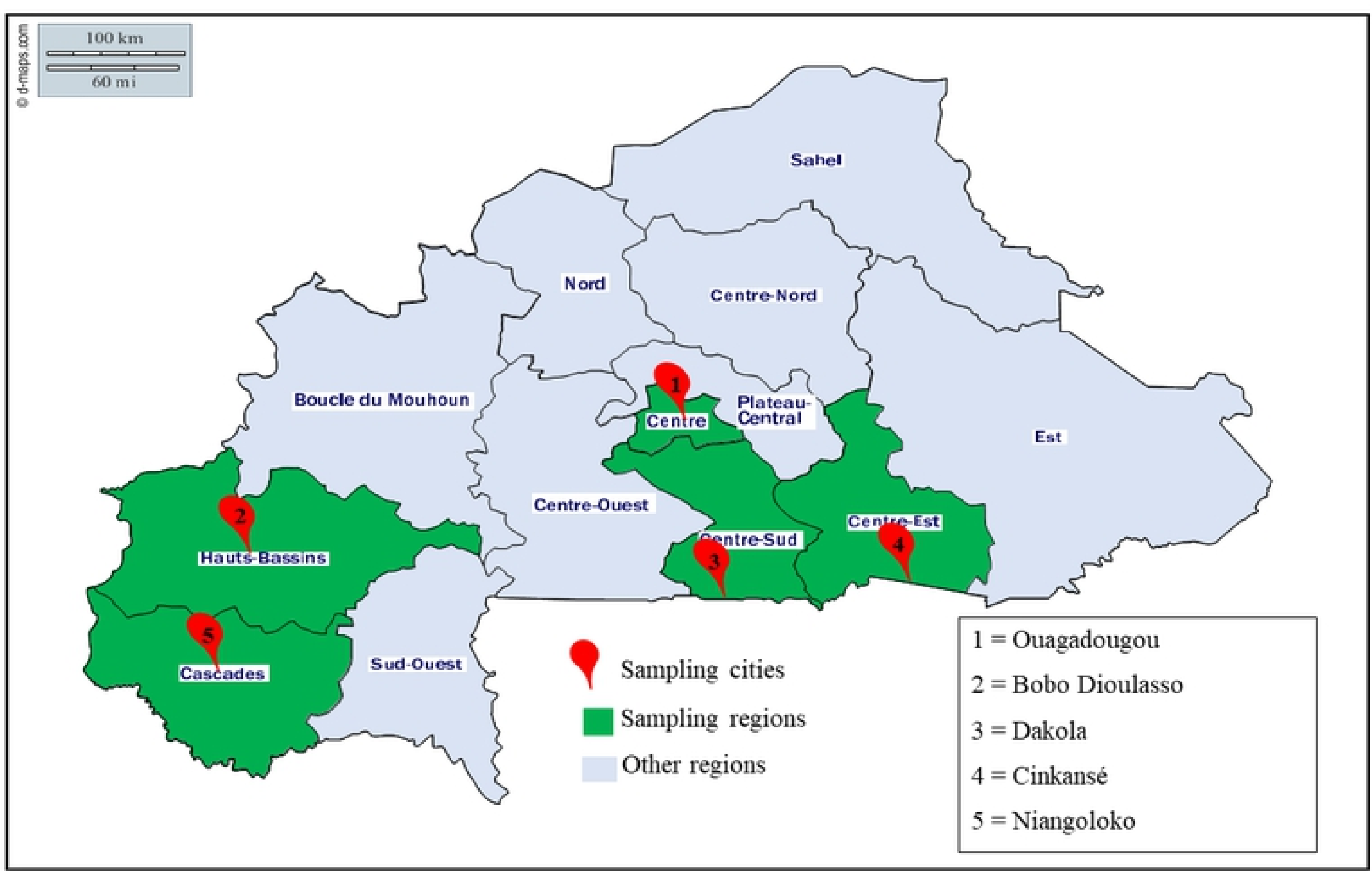

Figure 1 


\section{Overall appreciation}

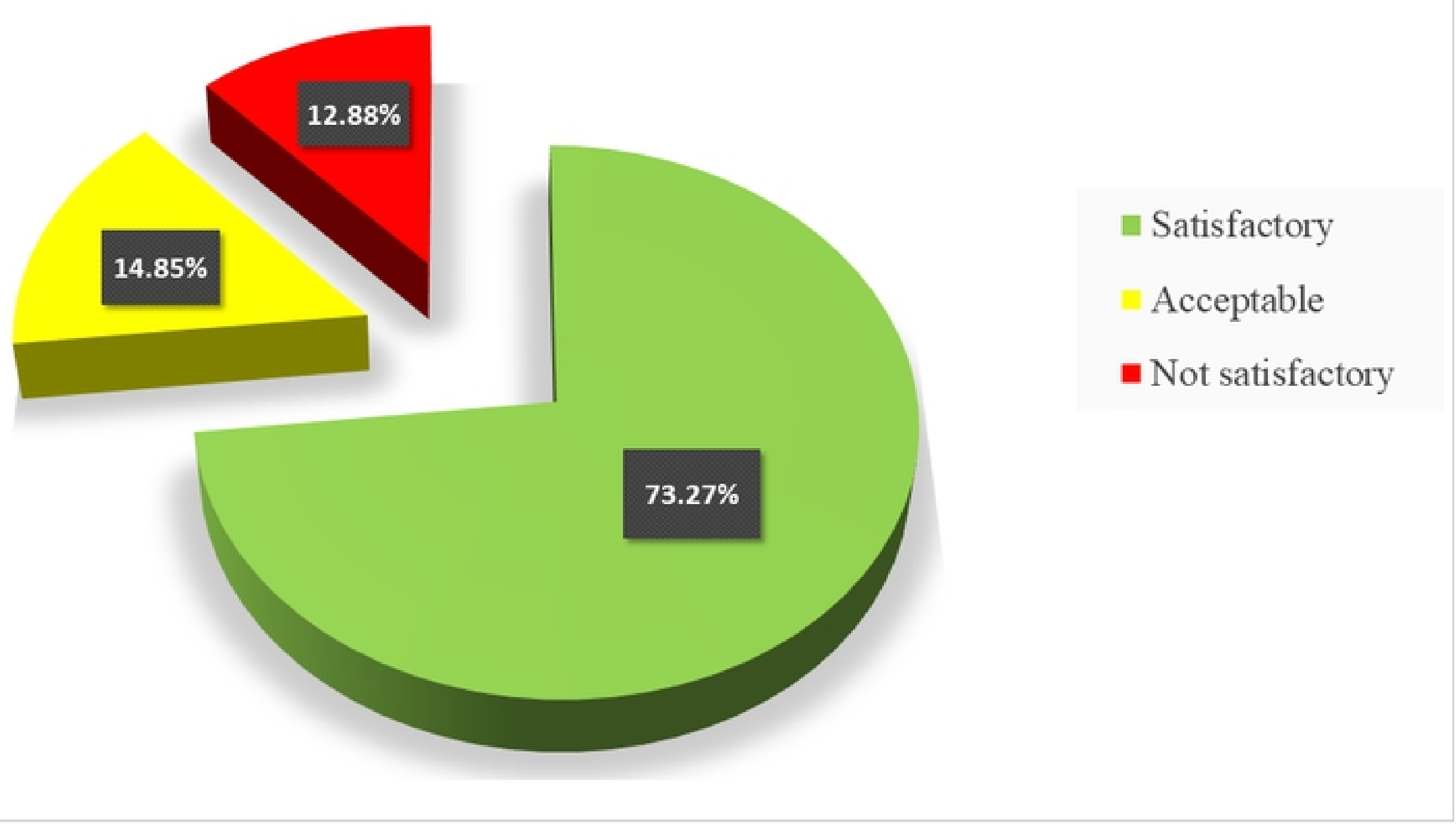

Figure 2 


\section{Appreciation according to cities}

20

15

10

5

0

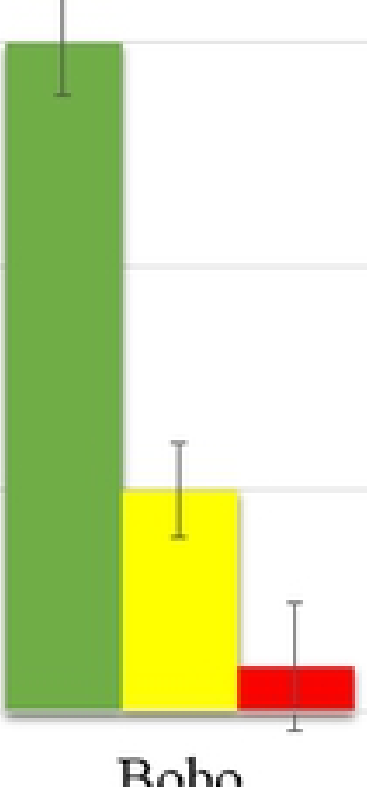

Bobo

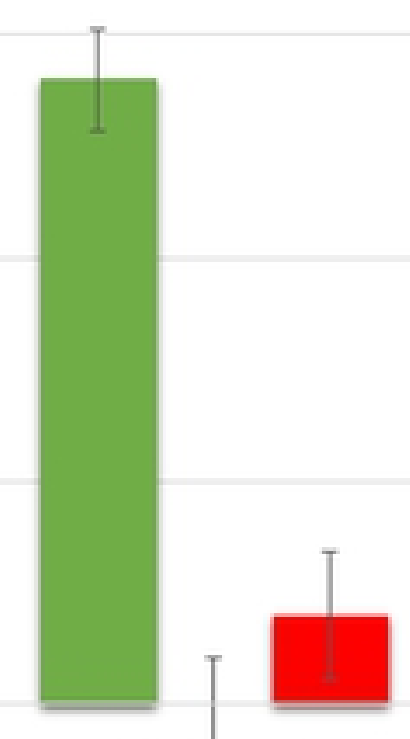

Cinkanse
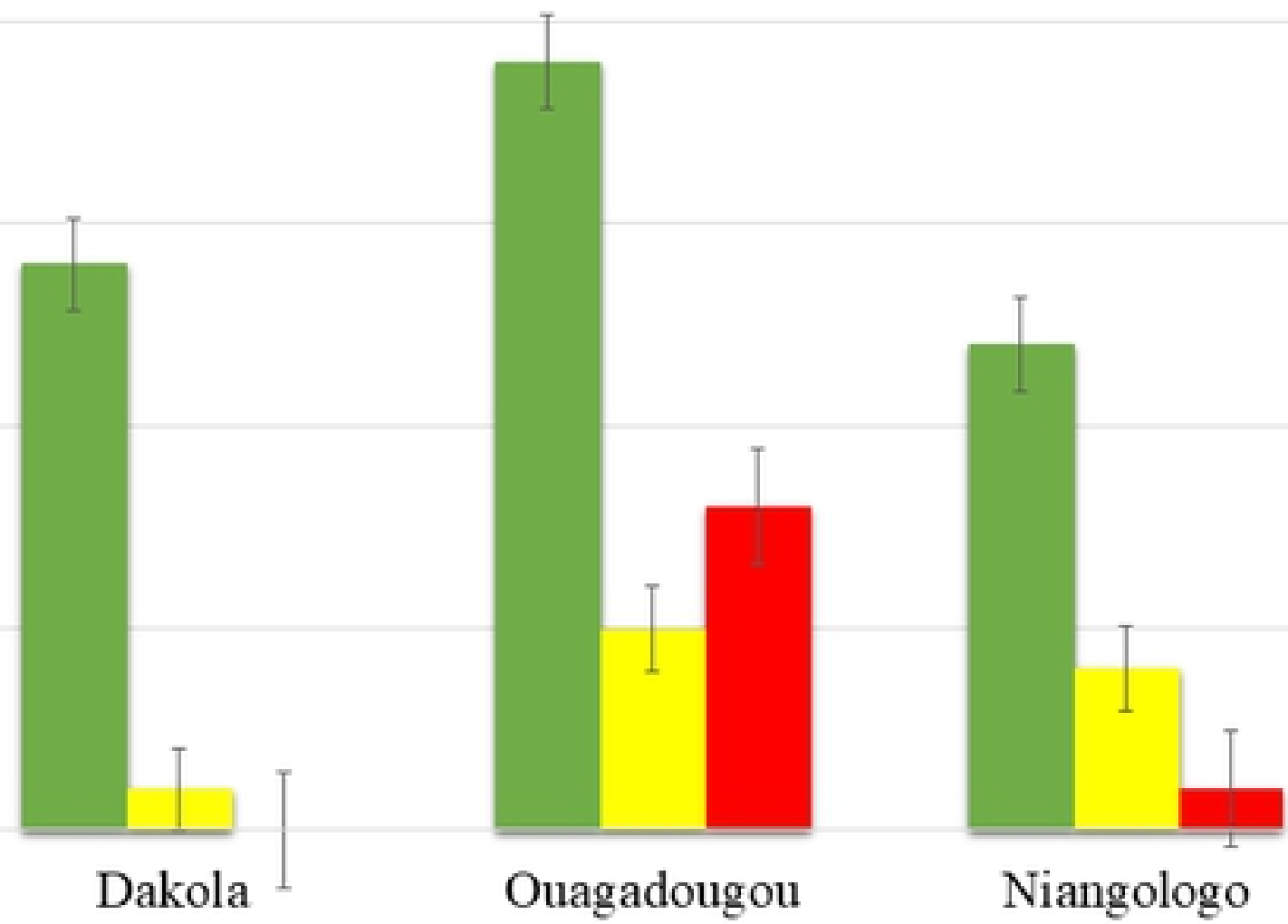

$-5$

घatisfactory Acceptable $\quad$ Not satisfactory

Figure 3 


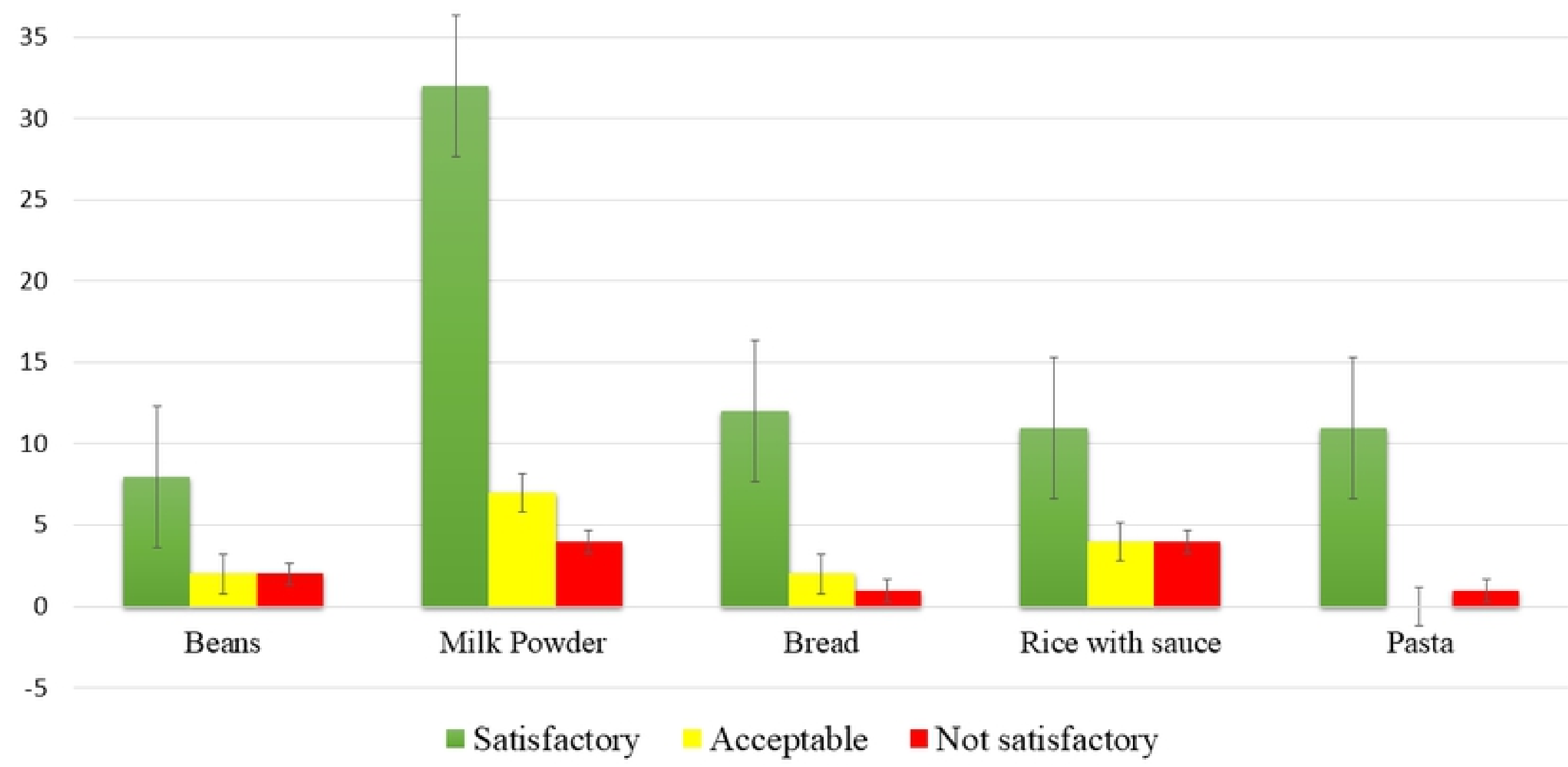

Figure 4 